\title{
THE ISSUE OF THE RESEARCH OF CRIMEAN TATARS' ETHNO-PSYCHOGENESIS AND ETHNIC AWARENESS
}

\author{
Osmanova A. M.
}

\section{INTRODUCTION}

The issue of the research of ethno-psychogenesis and ethnic awareness has a wide theoretic and empirical basis. At the same time, it is based on various understanding of ethnic essence, nature and structure. The study of ethnic awareness is taking place within various sciences, namely: philosophy, ethnology, psychology, and sociology etc. Based on the experience of awareness research one can state that a person, preserving stable mental structures inside, is still in constant self-search and self-development.

Marking the people clearly, ethnic self-awareness gives not much to the defining of common origin of people's group, namely in the reconstruction of "ethno-genetic bundles". . One should seek the basis of ethnic awareness not only in the people's ethno-genetic roots, but also in the information of cultural nature. Summarizing the set of basic paradigms of ethnic culture is no less meticulous and multifaceted task than the study of ethnic roots. Any phenomenon of spiritual and material culture, even the smallest one, may appear informative here. To catch the worldview integrity of ethnos, it is important to understand that every artifact of culture, whether it is a ritual, a phenomenon, an act, is bound by many indirect threads with one another, thus creating a certain balanced completeness, harmony of personality and the group, family and the surrounding world.

The study of the ethno-psychogenesis of any nation is a complex problem and is further complicated by the fact that it contains all the essential features of becoming an ethnic community in its historical retrospective. This, in turn, raises a number of difficulties, including in the interdisciplinary area. A comprehensive research of psychogenesis provides for the involvement of materials from the often unexpected fields of knowledge in the scientific circulation, including natural sciences, a

\footnotetext{
${ }^{1}$ Алексеев В.П. Етногенез : учеб. пособ. / В.П. Алексеев. - М. : Высш. шк., 1986. - 173 с.
} 
constant attraction to an interdisciplinary approach and a thorough possession of ethnology, archeology, mythology, etymology, etc. This circumstance leads to the necessity to develop optimal methodological foundations, in which the content and structure of the leading factors of genesis are almost decisive.

The process of ethno-genesis is basically the creation of a living "bundle of collective reality" 2 that can be formed only when it gathers a large and varied amount of potencies from the very beginning. Without such matter, the new "collective reality" will not be able to individualize by ethnic color. Ethnicity is based on the people's psycho-physiological features, caused by they gene pool, that is, ethnicity appears as a "specific set, a system of traditional forms of responses to surroundings, a set of common norms of behavior and activity. At the same time, the traditional form of reactions to the world or common norms of activity can have both social and natural origin",

Ethnologists quite fairly associate the origin of the particular people, primarily with a particular territory, with a particular geographical environment. The people adapt to the landscape by subordinating their activities to survival under these natural conditions (agriculture, cattle breeding, fishing, hunting, etc.) and create the culture associated with it. Crimea is no exception in this respect.

In recent years, a considerable amount of actual information on the ethnic history of Crimea has been accumulated. Numerous publications have covered various aspects of the history of the peoples having inhabited the peninsula. That is why there has been an urgent necessity to summarize the results of the studies conducted. This task has been solved in the article by A. Aibabin, O. Herzen, and I. Khrapunov, "The main problems of the ethnic history of the Crimea" rather successfully. It emphasizes that "the Crimean Tatar ethnos was formed mainly on the peninsula influenced by political, ethno-cultural, and denomination factors. In the steppe part of the peninsula, Turkic-speaking nomadic ethnic groups have repeatedly changed. Yet, in the first decades of the X century Pechenegs appeared here destroying the Bulgarian population in Eastern Crimea; and in the middle of the XI century Polovtsians settled. By the XIII century a mixed Pechenegs-Polovtsians ethnos was formed. In January 1223 the Tatars

\footnotetext{
${ }^{2}$ Алексеев В.П. Етногенез : учеб. пособ. / В.П. Алексеев. - М.: Высш. шк., 1986. - 173 с.

3 Бороноев А.О. Национальный характер и особенности развития России: механизм сопряжения / А.О. Бороноев., П.И. Смирнов // Регионология. - № 2. - 2001. - С. 208.
} 
invaded the Crimea. In the sources such ethnonym as "the Mongols" is not practically used for their description, but only "the Tatars". The excavation materials give a reason to talk about the fact that in the northwestern Black Sea region and the steppe Crimea there was no complete change of the population in the XIII century, and it was the same earlier in XI century"4.

Evaluating the current state of research on the Crimea ethnic history and its development prospects, the authors of the article note that "at present, the Crimean Tatars are an ethnos, with a consolidated awareness of their origin unity. In their surroundings, the idea of the ethno-genesis autochthonous nature is especially persistently spread, its initial stage being a priori identified with the Cimmerians, or Tauri",5. In conclusion, the authors make a categorical statement of the following content: "None of the present peoples living on the peninsula can be related to Cimmerians, Tauri, and Scythians by ethno-genesis. This connection with the early medieval ethnic communities is quite problematic as well",6.

Filling the existing vacuum in the theory of the Crimean Tatars' ethno-genesis, V. Vozgrin notes in the book "The Historical Fate of the Crimean Tatars" that the origins of the ethno-genesis of the present Crimean Tatar people go back to prehistoric times. According to V. Vozgrin, the gene pool basis of the Crimea includes Tauri, Cimmerians and Scythians. At the same time, a special place is given to the Tauri. "Most of our national and foreign scientists consider the Tauri to be Aboriginal of Crimea, moreover, with Indo-Aryan origin"7. V. Vozgrin believes that during the forced migration, the inhabitants of the steppes mostly descendants of the Huns, Bulgarians, Khazars, Pechenegs, Polovtsians left Crimea, but the mountain and south-coast population remained in their habitats. "The relationship between the autochthonous European and the strange, mainly Mongoloid, Asian population $<\ldots .>$ has changed dramatically in favor of the former"

There is another version of the Crimean Tatars' origin (R. Fazil, S. Nagaev, R. Muzafar). Thus, R. Fazil and S. Nagaev's article "Heart of the People" contains the concept of ethno-genesis of the Crimean Tatars,

\footnotetext{
4 Айбабин А.И. Основные проблемы этнической истории Крыма / А.И. Айбабин, А.Г. Герцен, И.Н. Храпунов // Материалы по археологии, истории и этнографии Таврии. - Симферополь : Таврия, 1993. - Вып. 3. - С. 117.

${ }^{5}$ Там само, с. 117.

${ }^{6}$ Там само, с. 118.

${ }^{7}$ Возгрин В.Е. Исторические судьбы крымских татар / В.Е. Возгрин. - М. : Мысль, 1992. - 446 с.

${ }^{8}$ Там само, с. $298-299$.
} 
different from that proposed by V. Vozgrin. "A large number of these tribes (Kipchaks) settled in the Crimea at that time, where they mixed with the local descendants of the Huns, Khazars, and Pechenegs, lived there, and then formed the ethnic basis of modern Crimean Tatars with them. Among such first Muslims of the Crimea in the XII - XIII centuries the first memorial of the Crimean Tatar language - the Kumanicus Code - was created. It is unanimous that the language of the Crimean Kipchaks was more developed and perfect than the dialects of the later hordes that came to the Crimea, in which various Turkic and Mongolian elements were mixed, and that is why the Kipchak language served as the basis for the formation of written, literary Crimean Tatar language""9.

R. Kurtiev introduces his concept of the ethno-genesis of the Crimean Tatars in the book named "Crimean Tatars: Ethnic History and Traditional Culture", whose central idea is the synthesis of two ethnic components that are very different from each other - the autochthonous non-Turkic agricultural population of the peninsula and the nomadic Turkic tribes, entering its territory not only once. The book traces the cultural assimilation of autochthonous peoples on the basis of Turkization and Islamization, proposes a new version of the periodization of the ethnic history of the Crimean Tatars, and studies theoretical problems of the relationship between the ethnonym of "the Tatars" and the ethnos of "the Crimean Tatars" $"$.

In the $\mathrm{X}$ century on the peninsula there is a Europeoid anthropological type of population with Turkic component of culture. With the arrival of the Turkic tribes - the Pechenegs (first half of the X century) and the Polovtsians (the middle of the XI century) - the second period in the history of the Crimean Tatars' ethnic core formation (kyrymlylar) begins, which can be called "Kipchak". Prior to the invasion of the Mongols (first quarter of the XIII century), an ethno-linguistic Pecheneg-Kipchak community formed on the peninsula, part of which settled in the foothills and southeastern Crimea, gradually mixing and dissolving in the local population, intensifying its Turkization. Later on, the Kipchaks of the peninsula steppes form the basis of the Crimean Ulus population of the Golden Horde (mid-XIII - the first half of the XV century), of the Crimean Khanate (the first half of the XV - the end of the XVIII century). After the

\footnotetext{
${ }^{9}$ Фазыл Р. Сердце народа / Р. Фазыл, С. Нагаев // Звезда Востока. - 1989. - № 3. - С. 135-143.

10 Куртиев Р. Крымские татары: этническая история и традиционная культура / Р. Куртиев. Симферополь: Б. и., 1998. - 151 с.
} 
conquest of the Crimea by Russia, the steppe Kipchaks of the Crimea are formed into an ethnic group of Crimeans. However, according to the author, the core of kyrymlylar continues to be the Turkic-speaking Muslim population of Taurica (the peninsula mountain and forest area). "During the period of joining the Russian Federation, deportation and residence in places of deportation in the republics of Central Asia (1944-1998), the process of forming a dialect-free people of the Crimeans was taking place" $" 11$.

A. Memetov in his work "Crimean Tatars: a Historical and Linguistic Essay" outlined the main ethno-genetic processes of the Crimean Tatars. Taking into account the commonality of language and culture, contemporary Crimean Tatars differ in their physical type depending on which groups participated in their ethno-genesis. The scientist has distinguished three main groups of Crimean Tatars: inhabitants of the Southern coast of Crimea, Tatars of mountain and foothills Crimea and steppe inhabitants of Crimea ${ }^{12}$.

Thus, the ethnic basis of the south-coast and mountain Tatars was the descendants of the Cimmerians, the Greeks, the Tauri, the Scythians, the Alans, the Goths, the Huns, the Genoese, and also partly the Khazars, the Polovtsians, the Seljuks Turks.

The ethnic basis of the steppe inhabitants of the Crimea was mainly Kipchak-Polovtsian tribes. The remains of the Khazars, Pechenegs, Guzy (Torc), partly Mongol-Tatars and Nogai participated in the ethno-genesis, mixing with the Kipchaks ${ }^{13}$.

The complex historical and ethno-genetic processes appearing after the formation of the Crimean Tatar people were reflected in their language. Tribal languages participated in the formation of the national Crimean Tatar language, mainly Kipchak and to a lesser extent Oguz, that is proved by the characteristic features of its basic dialects. Defining the place of the Crimean Tatar language among other Turkic languages, K.M. Musayev includes it in the West Kipchak group together with Kumyk, KarachayBalkar and Karaite ${ }^{14}$.

\footnotetext{
11 Куртиев Р. Крымские татары: этническая история и традиционная культура / Р. Куртиев. Симферополь: Б. и., 1998. - 151 с.

12 Меметов А. Крымские татары: историко-лингвистический очерк / А. Меметов ; [ред. С.К. Сосновский]. - Симферополь : Анаюрт, 1993. - 55 с.

13 Там само, с. 34.

${ }^{14}$ Мусаев К.М. Лексика тюркских языков в сравнительном освещении. Западнокыпчакская группа / К. М. Мусаев. - М. : Наука, 1984. - 226 с.
} 
E. Kudusov in his work "The History of the Formation of the Crimean Tatar Nation" associates the origin of the Crimean Tatars with a certain territory, a certain geographical environment and, based on this precondition, makes a conclusion that the native population of Crimea, so to say, an ethnic expression of its original nature is the Crimean Tatars, the Crimean Karaites and the Krymchaks are autochthons originating from peoples who lived there for 2.5 thousand years ${ }^{15}$.

In the formation of the Crimean ethnos (kyrymlylar) the author gives a special place to the Cimmerians, the Tauri, the Greeks, the Scythians, the Romans, the Sarmatians, and the Goths. However, according to E. Kudusov, the Turkic tribes of the Huns, Khazars, Pechenegs, Polovtsians were dissolved, found shelter in the mountains of the peninsula, who contributed to the formation of the native ethnos. At the same time, the Mongol-Tatars of the XIII century were quite easily assimilated by the aborigines of the Crimea. E. Kudusov makes an emphasis on the southern coastal area and mountains of the Crimea, which were a shelter for the steppe Crimea inhabitants from various conquerors and eventually became a cradle for the ethnos formation.

In his conclusion E. Kudusov justifies the idea of the Crimean Tatar nation emergence and development as a people's voluntary community united under the slogan of a single idea and future common goals, ready to uphold the order established by this state. The researcher identifies several stages in the period between XV-XVIII centuries and later on: the incubation period is based on the idea of separation from the Golden Horde and the achievement of independence; 1443 - legal registration of independence and creation of the Crimean Khanate; the stage of maturity, expressed in success in the economy, in foreign affairs, the termination of the national state existence, the transformation of Crimea into a province of the Russian Empire; Crimean Tatars' emigration; deportation and repatriation $^{16}$.

Yu. Zinchenko gives his version of the Crimean Tatars' ethno-genesis, according to which this process took place in two stages. The peninsula population was a complex ethnic group, uniting the descendants of the Cimmerians, the Tauri, the Scythians, the Greeks, the Sarmatians, the Alans, and the Goths before the invasion of the Huns. An intense process

\footnotetext{
${ }^{15}$ Кудусов Э. История формирования крымско-татарской нации / Э. Кудусов. - Б.м.: Б.и., 1996. - 32 с.

${ }^{16}$ Кудусов Э. История формирования крымско-татарской нации / Э. Кудусов. - Б.м.: Б.и., 1996. - 32 с.
} 
of assimilation was taking place between them, proving the existence of the term "Tauri-Scythian" in everyday life, as well as the archeological monuments of that time, in which the features of ancient Greek culture intertwined with the culture of the local population. The second stage is characterized by the prevalence of the Turkic tribes of the Huns, the Polovtsians, the Seljuks Turks, and others' influence. The process of the Crimean Tatars' formation as an ethnos continues in the XIII - XVI centuries as well. As a result, two main groups of the Crimean Tatars emerged in the Crimea: the steppe (northern Crimean) and southern coastal ones, which differ from each other in anthropological features and language ${ }^{17}$.

The given material gives an opportunity to consider in more detail and describe the tribes who participated in the ethno-genesis of the Crimean Tatar ethnos, as well as to reveal their direct reflection of reality, understand people's world perception and worldview.

Therefore, the first people in the territory of Crimea, having their own name, were the Cimmerians (IX - VII centuries BC). There are recollections about Cimmerian tribes in Homer's "Odyssey", Herodotus' "History", and some Minor Asian sources. Their religious worldview is characterized by faith in the soul and life after death. This is proved by excavations of burial mounds, where the things are found used by the dead during the life. In men's burials there are daggers, details of horse weapons, sometimes the remnants of the horse, arrowheads, sacrificial food. In women's burials there are gold and bronze temporal rings, glass, gold necklaces, and pottery.

In the Cimmerians, the emergence of the Mother Goddess' cult is indicated by steles depicting the woman having a cult nature. The Mother Goddess' cult is the most typical feature of the formation of many peoples' religious awareness. The feminine nature was the cradle song of all religions, which was fertilized and flourished from contact with male nature. Man and woman started the world, and the most expressive attributes of their gender were adored. Ancient religions also praised the love of the mother as the sole nurse and child protector.

One of the most ancient Crimean peoples were the Tauri who lived in the foothills and mountains of Crimea, as well as on the Southern coast.

\footnotetext{
17 Зінченко Ю. Кримські татари: Історичний нарис / Ю. Зінченко / Ін-т політ. і етнонац. досліджень НАН України. - К. : Голов. спеціаліз. ред. літ. мовами нац. меншин України, 1998. - С. 205.
} 
The ancient name of the mountain and coastal part of Crimea - Taurika, Tauriya, Taurida is originated from the Tauri. They left significant memories of themselves in the culture of the Crimean people, including material ones. It is possible to name many Scythian, Roman, Greek, Pontic and then Tatar settlements, built on the foundations of Taurian settlements and fortresses ${ }^{18}$.

With the expansion of the Scythians to the Crimea begins a new period of the peninsula history, characterized by qualitative changes in its population composition.

The Scythians' religion reached the developed polytheism. The Scythians stood on the verge of creating a national-state religion with a certain nation-wide pantheon of higher gods. The Scythian religiousmythological system combined the elements of zoomorphic symbolism of animal style with anthropomorphic mythologeme, elements of cattle breeding culture totems with the Greek mythology influence.

A wide range of Scythians' religious ideas prove the variety of Scythian religion forms: the cults of ancestors, heroes, tribal chiefs, the funeral cult and the fertility cult, whose objects were water, earth, plants, animals and the sun.

The Scythian state in the Crimea existed until the second half of the III century B.C. and was destroyed by the Goths (Scandinavian group of tribes).

The desire to self-identify inevitably provides for the awareness of these ethno-factors in the Crimeans creation, since the Crimean population was a complex ethnic group, consisting of descendants of the Cimmerians, the Tauri, the Scythians, the Greeks, the Sarmatians, the Alans, and the Goths. An intense assimilation process took place between them.

Understanding the Crimeans ethno-genesis requires awareness of Sarmatians' participation in it. They began to penetrate the Northern Black Sea in the last centuries B.C. This nomadic people, mostly Iranian, leaving the Lower Volga and the Cisurals, went to the West.

The Sarmatians' beliefs were not very different from those of the Scythians. Now one can speak of the inheritance of religious traditions. The cults of sun and fire and the Great Mother Goddess Astarte, the patron saint of horses, as well as the cult of the God of war, whose embodiment

\footnotetext{
${ }^{18}$ Храпунов И.А. Очерки этнической идентичности истории Крыма в раннем железном веке: Тавры. Скифы. Сарматы / И.А. Храпунов. - Симферополь : Таврия, 1995. - С. 78.
} 
was the sword, dominated in the Sarmatians. In addition, the factors of sensory-supersensory type of the supernatural can be found in the Sarmatians: worshiping the inanimate objects and endowing them with the soul, belief in the magical power of stones, and so on.

The Sarmatians believed in the afterlife, and therefore the cult of the dead was of great importance in their beliefs.

The same as with the Scythians, the Sarmatians gave a special magic power to the mirror. The Sarmatians' custom of breaking mirrors at burial was an echo of various ancient ideas, according to which the mirror as the receptacle of the soul was opposed to death. And at present, it is common to hang mirrors in a house where the deceased is present, and there is a belief that a broken mirror foretells death. At the same time, there is a ritual in which the mirror is a traditional attribute. It means the wedding ritual and the traditional fortune telling about the bridegroom.

Another factor declares itself in a reliable way - in the second half of IV century Turkic-speaking tribes appeared in the Crimea, Turkization of the local Hun population (according to other sources - Gun) began ${ }^{19}$. In the 70's of the IV century mass movement of the Turkic Hun tribes began (the Utigurs, the Kutrigurs, the Bulgars, the Akatsirs, the Sargurs, the Sabers, the Khazars, etc.). They open the first pages of the Crimea Turkic history, coming to replace the millennial rule of the Iranian tribes (the Cimmerians, the Scythians, the Sarmatians, etc.). From the second half of IV century the nomadic Iranian-speaking tribes are being replaced by the peoples of the Altai language group - the Huns, the Avars, the Bulgars, the Khazars. In 375 , the Ostrogothic Union was defeated by the Huns, nomads of Turkic origin who came from Central Asia and conquered by that time some Hungarian and Sarmatian tribes. Between 375 and 453, the Goths were part of the Hun state. And the Hun leader Attila was sung in the German epic literature. In general, it was a period when the Slavs, the Germanic people, the Hungarians, and the Turks mixed in one historical maelstrom, which in turn led to the formation of new ethnic groups. It is the Huns who were in the center of this maelstrom, who conquering and uniting Germanic, Slavic, Sarmatian and Thracian tribes around them. At the same time, one should speak about mutual assimilation, especially when it comes to religion.

\footnotetext{
19 Кіндратенко А.М. Європейські гуни в описах давніх авторів / А.М. Кіндратенко. - Х. : Курсор, 2007. -359 c.
} 
These tribes, which later were dissolved among the Turkic-speaking descendants of the Crimean Tatars, left a mark in their memory, introducing a large number of Iranian origin elements into the language and culture. There was no cultural influence or any noticeable racial mixing of the coastal and mountain population of the Crimea with the Hun conquerors.

At the end of VII century in the Northern Black Sea region, in the steppe of Crimea and Sugdei (modern Sudak) the Khazars appeared. The Khazar religious view corresponded to the ancient Turkic religion. The supreme deity was Tengri, who represented the supreme power. Hagan was his vicegerent on earth. Hagan had a political charisma, so, he belonged to a family endowed with divine grace. Thus, like the Germanic people, the Turkic Khazar association was also one of the options of male unions governed by the charismatic king (Hagan).

Yet, in the VII century the Crimean Khazars were pagans, they "made sacrifices to fire and water, worshiped some gods of the roads, as well as the moon and all the creatures that seemed unusual to them" (Kagankatvatsy M., 1861, 90). So, divine substance is multifaceted, however fire and water were central, the supreme deity was Tengri-Khan. Khazar paganism was a complex amalgam of cults of different content and origin $^{20}$.

The Khazars played an important role as mediators in the cultural relations of the West and the East. The cultural significance of Khazaria was religious patience and tolerance to such religions as Buddhism, Christianity, Judaism, and the pagan religion of the Slavs. In the capital of Khazaria, Itili, Muslims had their mosques, Christians had churches, and Jews had chapels. There were also special courts for Muslims, Khazars, Christians and representatives of other religions. All this contributed to the rapprochement, cooperation and enrichment of different cultures.

After Attila's death (453), the Hun state was disintegrated. It is at that time when the Bulgar tribes appear in Eastern Europe. They were descendants of the Huns and Alan tribes of the Bulgars and inherited their religious traditions. They are sometimes called the Hun Bulgars. A strong state association - Greater Bulgaria, which included part of the modern Ukraine territories, was created by the Huns-Bulgars. Therefore, the

\footnotetext{
${ }^{20}$ Артамонов М.И. История хазар / [ред. совет: А. Я. Дегтярев (предс.) и др.]. - 2-е изд. - СПб : Лань, 2001. $-687 \mathrm{c}$.
} 
Bulgars could not stay away from the ethno-genetic and culture-creating processes that were taking place in the region at that time.

The history of the Bulgars is closely intertwined with the history of the Turkic tribes (the Huns, the Avars, the ancient Turks, and the Khazars). Fragments of the Bulgars' specific culture have been preserved in the historical memories and rituals of the Crimean Tartar mountain dwellers. They inherited the worship to fire. At the wedding, in particular, according to the old custom, the bridegroom should have a decorated rooster on the table ${ }^{21}$.

In the second half of the XI century Kipchaks entered on the peninsula territory, in addition to its mountainous part. One of the numerous Turkic tribes was called Polovtsians in Rus. They believed in the god of Heaven Tengri, worshiped the cult of the wolf (boru, kurt) and the snake (jilan) ${ }^{22}$. In the XI century most Polovtsians accepted Islam. Among the Polovtsians spiritual heritage, we can name such oral Arabic folklore as "Leila and Majnun", "Yusuf and Zuleika", later on - "Ashik-Garib", anecdotes about Hodja Nasredin, common for Islamic world, which enriched the Crimean folk cultural heritage.

By touching the history of the past times, we raise incredible cultural layers that are common, cognate for different peoples. Under the thickness of religious consciousness is a powerful stratification of archaic stereotypes of world's practical and intellectual assimilation. Religion was associated with the nature spiritualization, with its anthropomorphic properties and features. People felt as an integral part of the environment, a factor of the cycle of natural phenomena. The history of religion of a particular ethnos is, first of all, the history of its spirituality, the core of which is religion. The originality of Crimean Tatar religiosity is determined by the unity of culture and the natural environment. Its origins should be found in ancient times. The establishment of Crimean Tatar people's religiosity is closely connected with the assimilation of the components of other peoples' religiosity with which its historical paths intersected. And it still preserves that lively connection with other cultures.

As it was already mentioned, in the XII - XIII centuries the first dictionary of the language kyrymlylar, namely the "Kumanicus Code" was

\footnotetext{
${ }^{21}$ Очерки истории и культуры крымских татар / [под ред. Э. Чубарова]. - Симферополь : Крымское учебно-педагогическое государственное издательство, 2005. - 208 с.

22 Герасимова М.М. Антропология античного и средневекового населения Восточной Европы / М.М. Герасимова, Н.М. Рудь, Л.Т. Яблонский. - М. : Наука, 1987. - С. 218-221.
} 
created in Crimea. Therefore, the complex historical and ethno-genetic processes that contributed to the formation of Crimeans were reflected in its language. Kipchak and to some extent Oguz tribes took part mainly in the formation of this language, as evidenced by the typical features of its basic dialects. Therefore, the language of the Crimeans belongs to the Kipchak-Oguz subgroup of the Turkic group of the Altai language family ${ }^{23}$.

The Crimean Tatars went through a difficult and long journey in their development - from a multi-tribal union to a Crimean Tatar ethnos, which is proved by specific forms of material and spiritual culture reflected in people's bright, original features.

Within the culture established, the Crimean Tatars created their own system of rules and norms of behavior in society and family, based initially on the simplest moral ideas of good and evil, respect for the elders, hard work and collectivism. Gradually, bans and customs are being transformed into mechanisms of moral regulation, the nature of which is determined by the social way of life. Rich ethnic roots have made a significant impact on people's moral features.

The tribes of the Huns, the Turkic-Bulgars, the Khazars, the Pechenegs, the Polovtsians largely kept the heritage of the ancient ("Altai", "Siberian") Turkic civilization in their culture. During the period of tribal consolidation, statehood establishment and the Crimean Tatar people's formation, the achievements of the inhabitants of the mountain and coastal parts of the peninsula such as the Tauri, the Cimmerians, the Scythians, the Sarmatians, the Ancient Greeks, the Alans, the Goths and the Byzantines contributed to the culture as a significant component. It can be traced in the mythology and folk knowledge of the Crimean Tatars, as well as in the development of their material culture.

A new stage in the ethno-psychological development of the Crimean Tatars' society was associated with the spread and promotion of Islam in the Crimean territory.

The most significant stages in the formation of the Crimean Tatar people and their worldviews are related to the period of the Crimean Khanate (1443-1783). The process of ethno-psychogenesis of Crimeans

\footnotetext{
${ }^{23}$ Меметов А. Крымские татары: историко-лингвистический очерк / А. Меметов ; [ред. С.К. Сосновский]. - Симферополь : Анаюрт, 1993. - 55 с.
} 
took place on the background of the Islamic canon transformation into a national tradition, way of life and awareness of the people.

In fact, Islam has had a great influence on the formation of the Crimean Tatar people, one of the two autochthonous peoples of Ukraine, from the first years of its existence on the Crimean peninsula. It is on the lands of the Crimea in the period from XIII to XVI centuries that the formation of the Crimean Tatars as a separate ethnos with its religion Islam took place. At the same time, the Crimean peninsula remained the main channel for the Dnieper region people to find out about Islam and Muslims for a long time.

However, contacting with the Muslim world, the Khans saw Islam as a powerful spiritual tool for consolidating the young people and building a strong system of political power in the state based on Sharia (Islam legal system).

Even Khan Ugedei, the son of Genghis Khan, began to treat Muslims kindly. However, the younger brother of Batu Khan - Golden Horde Khan Berke (XIII century) became a passionate proponent of Islam. Becoming a Muslim, he began to actively spread it in the Crimean Ulus. This process has intensified significantly since Berke allowed the Seljuk Turks to come to the peninsula, giving the Sudak fortress to Turkish sultan Iz-ed-Din.

However, the final establishment of Islam in the Crimea took place under Khan Uzbek (1313-1342), who officially introduced Islam as the state religion on the peninsula. Khan lived in the Crimea for some time himself, considered to be an example of adherence to Islam requirements. The legendary Tamerlane (1336-1405) completed Islamization of the Turkic-speaking population of the Crimea. Eliminating Khan Tokhtamysh, he included the peninsula in the composition of his great empire. In his policy, Tamerlane relied on Muslim clerics and promoted Islam in every possible way.

Later on, after the end of the Golden Horde period of its history, the Crimean Ulus was separated as an independent state formation, on the basis of which an independent Crimean Tatar state appeared. Since 1427 it had been under the rule of the Khans dynasty of the Girayev (Geraev) clan.

In 1475 a new period in the history of the Khanate began. That year, the Ottoman Turks, entering the peninsula, conquered the Crimean Tatar state. The rulers of Crimea became vassals of Istanbul. The affairs of the state were performed by Turkish officials appointed by the Sultan. 
Muslims' religious life on the peninsula came under the control of the Ottoman Empire as well. All high-ranking clerics were appointed with the participation of Sultan's representative, whose name was considered sacred, and was praised daily in the Crimean mosques.

The unification of secular state and religious power took place. Khan was started to be considered as Mufti (leader) of Muslims. Clerics became an influential political force in the state. The Mufti of Crimea was part of the State Council of the Empire - Divan. Further places in the hierarchical steps were occupied by cadi (Sharia judges), mudaris (responsible for teaching in Muslim schools - maktib), imams, sheikhs (heads of Muslim fraternities), souffah (members of brotherhoods or hermits). They took care of the Crimeans' education in the spirit of Islam, taught them the observance of its regulations, and educated faithful Muslims and honest citizens. Islam became the basis of the spiritual life of the Crimean Tatar people. Almost all major settlements had acting mosques, numbering at least 1.5 thousand in total. The Muslims of Crimea were successive Sunnis, although some in the North Caucasus brought Sufism here, and dervishes lived in Yevpatoria (Gezlev). Sheikh-ul-Islam was the leading authority on Muslim law, the head of the Ulema (theologians), whose title was introduced in the Ottoman Empire in 1424.

Under the influence of Islam ideas and norms, the Crimean Tatar people's national culture, their everyday traditions, language, way of life, system of education and children's upbringing was formed; writing, bookcreating, music, stone and wood carvings, ornamental art and especially architecture flourished. The city of Old Crimea is rich in valuable monuments of Muslim architecture with mosques of Uzbekistan and Babars, Kurshun-Jami and Takhtali-Jami, with madrasas, caravanserai and fountains. Many monuments of Muslim culture are in Bakhchisarai city, the former administrative center of the khanate: a palace, a mosque, and a rich collection of medieval Muslim literature in the past. The centers of the Muslim civilization of Crimea were also Karasu Bazaar (Belogorsk), Kafa (Feodosia), Gezlev (Yevpatoria) with its unique Juma-Jami Mosque (1552).

The series of brilliant Muslim culture figures flourished. They included, first of all, Khan Khoja-Devlet-Giray, Remal-Khoja, SeidMuhammad-Riza and many others. 
Under the influence of Islam ideas and norms, people's national culture, their everyday and family traditions, language, way of life, system of education and children's upbringing was formed, as well as art, writing, architecture were revealed, adapting to the doctrine, included in the existing system of religious rituals. This is proved by the peculiarity of Turkic Muslim epitaphs of the XIV century from Eski Yurt ${ }^{24}$.

Complex ethnic processes of assimilation and mutual cultural penetration, political processes aimed at the creation of a separate state (firstly - the Crimean Ulus, and then - the Crimean Khanate), led together to the emergence of a unique ethnic formation - Crimeans (kyrymlylar), united by the community of territory, languages, and religion.

Thus, our scientific analysis showed that the rich culture of the Crimean Tatar people was formed in an active connection with the process of its ethno-genesis. Due to the geographical location of the Crimea, being at the crossroads of the most important trade routes of old times (the Balkan- Caucasian, the Black Sea-Asia Minor and the Great Silk), the traces of mutual influence of different peoples in the culture, along with purely national, traditional things can be seen.

However, despite its external influence, the Crimean Tatar spiritual culture preserved its identity, developing a tradition of humanism and patriotism. Cultural achievements, penetrating from outside, were transformed and mastered taking into account the peculiarities of the local economy, housekeeping, geographical environment and traditions of the Crimean Tatars. The peculiar and original spiritual culture of the Crimeans, which at first differed with the complexity of its origins, resulted in one of the remarkable phenomena of world culture in the further development. In the Crimeans' culture a complex of certain value-oriented phenomena has been processed, making up the core of cultural and psychological attitudes, which make it possible not to lose their identity and originality.

Ethno-psychological features of the people are in close interaction with its culture and history. The pattern of formation and development of national character traits occurred at different stages of evolution just as its national awareness. "Each nation has its own special spiritual inner world, reflecting its social, geographical, ethnic, linguistic and other features", V.D. Popov argued, - and people's soul is their public psychology, so it 31 .

${ }^{24}$ Иванов А.А. Надписи из Эски Юрта в XII-XVI вв. / А. А. Иванов. - Ростов-на-Дону, 1989. - С. $24-$ 
includes such common grounds of spiritual life of each person that shape person's national character, traditions, customs, and habits. The better is the psychological health of the people, the stronger their spirit" 25 .

The national character of any nation is genetically predetermined by a long evolutionary process. The features of mental composition, types of thinking are determined not only by historically formed traditions, social environment and education, but also by hereditary potential. "In every nation, according to F.H. Cassidy, all types of temperaments, varieties of mind, and perception of the surrounding reality are represented <...> Moreover, the national character is not simply reduced to the psychic peculiarities of the people, which are most common in them. National character is a unique combination of distinctive features of a certain nation $\langle\ldots>$ Every nation is a kind of individuality, living integrity, the main features of which are the peculiarities of mental composition and types of thinking ${ }^{26}$. This is also emphasized by M.O. Lossky: "the natural originality of the national character provides for the preservation of a peculiar national face. In preservation and development of national identity, in addition to the natural strength of the people, further promotion of national upbringing and education is required" 27 . In his opinion, the main means of upbringing should be intellectual and emotional-volitional application to a specific life, to the content of national character, and national creativity.

Thus, the analysis of individual aspects of ethnic life, different driving forces of ethnic development makes it possible not only to describe the history of the people, to generalize and consider the regularities of the ethnic process, but also to identify those specific features that are the basis of ethnic awareness.

Self-identification in the first sources of ethno-psychogenesis of the Crimean Tatars remains a complex multidisciplinary scientific problem. First of all, the difficulty is in dating the point of reference of the people formation, because it is not about a one-time event but a long evolutionary process. In essence, the achievement of reasonableness, naturally complete image of kyrymlylar occurred as a result of numerous migration, assimilation, cultural-mixing processes, which, ultimately, leads to the

\footnotetext{
25 Попов В.Д. Психология и экономика / В.Д. Попов. - М.: [б. и.], 1989. - 304 с.

${ }^{26}$ Кессиди Ф.Х. Народ и нация / Ф.Х. Кессиди // Философия социологической мысли. - К., 1992. № 6. - С. 36-37.

27 Лосский Н.О. Характер русского народа / Н. О. Лосский. - М. : Даръ, 2005. - 336 с.
} 
formation of an integrated, anthropological, psychological, ethnic organism. Its ethno-psychological characteristic represents all ethnogenetic factors of previous evolutionary tendencies. Through the prism of such reflections, we have to consider the historiographical provisions explaining the origin of kyrymlylar.

Natural-geographical conditions and historical features of people's development, which determine the nature of work, games, holidays, traditions and ceremonies, the content of oral folk art, fine arts and folk crafts, the specifics of relations between people and attitudes to the environment constitute a variable characteristic of the ethno-psychology of the Crimeans. All that, in the end, contributed to the formation of such psychological features of the Crimean Tatar people as love for their native land, spirituality, collectivism, peacefulness, hard work, freedom, courage, tolerance etc.

A general approach to understanding the social norms and normative behavior gives an opportunity to identify the nature and types of normative behavior as well as the psychological mechanism of behavior in Crimean Tatar ethnic society. The material analyzed makes it possible to expand and deepen the understanding of the sources of behavioral, spiritual and moral structures of the Crimean Tatar ethnic group in our study. For many centuries, the Crimean Tatars formed their own system of rules and norms of behavior, enshrined in specific forms of folk art (crafts, traditions, customs, holidays, rituals, folklore, games, etc.), which together formed the basis of folk psychology.

Ethno-psychology of the Crimean Tatar people is based on the laws of the socio-psychological system: the presence of the ideal of personality, fixed in the sources of people's spiritual culture; interaction of social requirements; upbringing factors: nature of Crimea, history of Crimean Tatar people, including Crimean Khanate; Muslim religion, social way of life; multinational and multi-denominational nature of Crimea.

Ethnicity, reflected in the spiritual culture samples of the Crimean Tatars, is in the narrowest sense a universal vector of an ethnic idea, demonstrating the inseparability of ties with its historical past. Awareness of inseparability of these ties with the past, its succession is one of the significant markers of ethnic self-determination of the kyrymlylar (Crimeans). The Crimean Tatars' self-awareness is primarily related to the need for ethnic integrity. 


\section{CONCLUSIONS}

Ethnic awareness and self-awareness are most adequately explained within the scientific paradigm according to which traditional ethnic culture of ethnos is the way and result of group adaptation to new conditions. That is why an adequate analysis of evolutionary development stages of the Crimeans' ethnic awareness is possible in case of turning to the psychology, history, culture and religion of the Crimean Tatars.

It is detected that the roots of the Crimean Tatars's ethnic awareness are very deep and refer to the period of origin and formation of this ethnos. Since the ethno-genesis of the Crimean Tatar ethnos is based on a mixture of the autochthonous population of Crimea and the Turkic tribes, it is this objective factor that has determined the identity of the Crimean Tatar ethnic awareness.

A new stage in the ethno-psychological development of the Crimean Tatar society was associated with the spread and promotion of Islam in the Crimea. Islam defined the vector of spiritual fullness of the Crimean Tatars' ethnic awareness.

\section{SUMMARY}

The article "The issue of the research of Crimean Tatar's ethnopsychogenesis and ethnic awareness" deals with the main tendencies and areas in the study of ethno-genesis, ethnic awareness and ethnic culture of the Crimean Tatars.

It is noted that the Crimean Tatars in their development went through a difficult and long journey from a different tribal union to the Crimean Tatar ethnos, confirmed by the specific forms of material and spiritual culture reflected in the people's bright, original features.

Within the culture established, the Crimeans created their own system of rules and norms of behavior in society and family, based initially on the simplest moral ideas about good and evil, respect for the elders, hard work, and collectivism. Gradually, bans and customs are transformed into mechanisms of moral regulation, the nature of which is determined by the social way of life. Rich ethnic roots had a great influence on the moral features of the people. In people's culture, a complex of certain valueoriented phenomena was processed, making up the core of cultural and psychological attitudes, making it possible not to lose their identity and originality. 


\section{REFERENCES}

1. Айбабин А.И. Основные проблемы этнической истории Крыма / А.И. Айбабин, А.Г. Герцен, И.Н. Храпунов // Материалы по археологии, истории и этнографии Таврии. - Симферополь : Таврия, 1993. - Вып. 3. - С. 117.

2. Алексеев В.П. Етногенез : учеб. пособ. / В.П. Алексеев. - М. : Высш. шк., 1986. - 173 с.

3. Артамонов М.И. История хазар / [ред. совет: А.Я. Дегтярев (предс.) и др.]. - 2-е изд. - СПб : Лань, 2001. - 687 с.

4. Баскаков Н.А. Очерки истории функционального развития тюркских языков и их классификация / Н.А. Баскаков ; [отв. ред. Б. Чарыяров] / АН ТССР, Ин-т яз. и лит. им. Махтумкули Ашхабад: Ылым, 1988 - 138.

5. Бороноев А.О. Национальный характер и особенности развития России: механизм сопряжения / А.О Бороноев., П.И. Смирнов // Регионология. - № 2. - 2001. - С. 208.

6. Возгрин В.Е. Исторические судьбы крымских татар / В.Е. Возгрин. - М. : Мысль, 1992. - 446 с.

7. Герасимова М.М. Антропология античного и средневекового населения Восточной Европы / М.М. Герасимова, Н.М. Рудь, Л.Т. Яблонский. - М. : Наука, 1987. - С. 218-221.

8. Зінченко Ю. Кримські татари: Історичний нарис / Ю. Зінченко / Ін-т політ. і етнонац. досліджень НАН України. - К. : Голов. спеціаліз. ред. літ. мовами нац. меншин України, 1998. - С. 205.

9. Иванов А.А. Надписи из Эски Юрта в XII-XVI вв. / А.А. Иванов. - Ростов-на-Дону, 1989. - С. 24-31.

10. Кессиди Ф.Х. Народ и нация / Ф.Х. Кессиди // Философия социологической мысли. - К., 1992. - № 6. - С. 36-37.

11. Кіндратенко А.М. Свропейські гуни в описах давніх авторів / А.М. Кіндратенко. - Х. : Курсор, 2007. - 359 с.

12. Кудусов Э. История формирования крымско-татарской нации / Э. Кудусов. - Б.м.: Б.и., 1996. - 32 с.

13. Куртиев Р. Крымские татары: этническая история и традиционная культура / Р. Куртиев. - Симферополь: Б. и., 1998. - 151 с.

14. Лосский Н.О. Характер русского народа / Н.О. Лосский. - М. : Дарь, 2005. - 336 с. 
15. Меметов А. Крымские татары: историко-лингвистический очерк / А. Меметов ; [ред. С.К. Сосновский]. - Симферополь : Анаюрт, 1993. - 55 с.

16. Мусаев К.М. Лексика тюркских языков в сравнительном освещении. Западнокыпчакская группа / К.М. Мусаев. - М. : Наука, 1984. $-226 \mathrm{c}$.

17. Нордан М.В. Илам в Евразии: современные этические и эстетические концепции суннитского Ислама, их трансформация в массовом сознании и выражении искусстве мусульманских народов России / М.В. Нордан, Р.Г. Кузеев, С.М. Червонная. - М. : ПрогрессТрадиция, 2001. $-516 \mathrm{c.}$

18. Очерки истории и культуры крымских татар / [под ред. Э. Чубарова]. - Симферополь : Крымское учебно-педагогическое государственное издательство, 2005. - 208 с.

19. Попов В.Д. Психология и экономика / В.Д. Попов. - М.: [б. и.], 1989. - 304 с.

20. Фазыл Р. Сердце народа / Р. Фазыл, С. Нагаев // Звезда Востока. - 1989. - № 3. - С. 135-143.

21. Храпунов И.А. Очерки этнической идентичности истории Крыма в раннем железном веке: Тавры. Скифы. Сарматы / И.А. Храпунов. - Симферополь : Таврия, 1995. - С. 78.

\section{Information about the authors: Osmanova A. M.}

Candidate of Psychological Sciences, Associate Professor at the Department of Psychology and Pedagogy of the Educational and Scientific Humanitarian Institute of the. I. Vernadsky Taurida National University 33, Ivana Kydri str., Kyiv, 01042, Ukraine 